\title{
PELATIHAN DAN PENDAMPINGAN DAI MUDA SEBAGAI UPAYA PENYIAPAN BENTENG DAKWAH WILAYAH MUSLIM MINORITAS PAPUA BARAT
}

\author{
Agus Yudiawan ${ }^{1}$, Ahmadi ${ }^{1}$ \\ ${ }^{1}$ Institut Agama Islam Negeri Sorong, Papua Barat, Indonesia \\ email agusyudiawan@stainsorong.ac.id
}

\begin{abstract}
Abstrak: Pengabdian masyarakat ini bertujuan untuk meningkatkan kualitas dai muda di wilayah minoritas muslim Papua Barat. Metode dampingan menggunakan Participatory Action Research (PAR). Peserta dampingan sebanyak 20 orang mahasiswa IAIN Sorong. Pendampingan ini menggunakan empat tahapan yaitu, tahap perencanaan, tindakan, observasi, dan refleksi. Hasil pendampingan menunjukkan bahwa kompetensi dai muda peserta pendampingan mengalami peningkatan cukup signifikan (18\%). Pada kondisi awal, memiliki kompetensi kurang baik $(58,1 \%)$ dan berhasil ditingkatkan menjadi baik (76,0\%). Kesimpulannya, pendampingan dan pelatihan dapat menjadi pilihan akademis dalam penyiapan dai muda sebelum berkontribusi di masyarakat, khsusunya pada wilayah minoritas muslim di Papua Barat.
\end{abstract}

Kata Kunci: pelatihan dan pendampingan, Dai, minoritas muslim

\begin{abstract}
This community service aims to improve young preachers' quality in the Muslim minority area of West Papua. The mentoring method used Participatory Action Research (PAR) and involved 20 students of IAIN Sorong. It followed four stages, namely, the planning, action, observation, and reflection stages. The mentoring results showed that the young participants' competence in mentoring had increased quite significantly (18\%). They initially had low competence (58.1\%) and were successfully upgraded to good (76.0\%). In conclusion, mentoring and training can be an academic choice in preparing young preachers before contributing to society, especially in Muslim minority areas in West Papua.
\end{abstract}

Keywords: training and mentoring, Dai, muslim minority

\section{Pendahuluan}

Wilayah Papua Barat mengalami defisit dai. Padahal sebaran masyarakat muslim di wilayah Papua terfokus pada wilayah ini. Menurut Tokoh Islam (Rais Syuriah PWNU) Papua Barat, bahwa wilayah Papua Barat hingga kini, belum banyak memiliki dai yang unggul dan ter verifikasi, sementara lainnya adalah dai dadakan yang dipercaya masyarakat mampu memberikan ceramah atau khutbah (Ahmadi, 2020). Kondisi ini sangat miris, mengingat cukup banyak pesantren (18 pesantren) yang sebenarnya sebagai Lembaga penghasil dai mumpuni, (Pdppkemenag, 2019; Yudiawan, 2020). Selain itu, keberadaan Perguruan Tinggi Keagamaan Islam Negeri (PTKIN) di Papua Barat, IAIN Sorong sudah seharusnya mampu turut andil dalam penyiapan kualitas sumber daya dai (lulusan) yang tidak hanya paham agama, namun juga pemahaman keilmuan yang lebih baik. Lulusan PTKIN terus menjadi sorotan masyarakat, dimana harapan pengembangan keagamaan jatuh padanya. Lulusan (mahasiswa) sudah semestinya mampu menjawab persoalan ini. Posisi sebagai agen of change, iron stock dan social control (Ramadhan, 2015) menjadi cambuk motivasi dalam melakukan transformasi keagamaan di masyarakat. Olehnya, penguatan dari sisi ilmu dakwah menjadi suatu yang sangat urgen dan mendesak. 
Studi terdahulu yang fokus mengkaji isu kompetensi Dai di wilayah Papua Barat belum banyak dilakukan. Padahal Dai merupakan instrumen dakwah yang mampu merekonstruksi harmoni di bumi cenderawasih (Mashad, 2015). Jika dilihat dari sisi keilmuan, kondisi ini akan menimbulkan kesenjangan yang membutuhkan tindakan solutif melalui pengabdian berbasis penelitian (riset). Jika sudut pandang diperluas, studi yang ada umumnya terfokus pada masyarakat pada wilayah-wilayah yang notabene merupakan basis keislaman. Misalnya, studi yang dilakukan oleh Ayub yang melakukan pendampingan di wilayah Kendari Sulawesi Tenggara (Ayyub, 2012), dimana kajiannya sebagai bukti pengimplementasian moto Kota yaitu "Kendari Kota Bertakwa". Selain itu menyoal penguatan dai multi peran dalam masyarakat sesuai sosio historis di wilayah Yogyakarta (Risdiana, 2014), pelatihan khatib dan mubaligh di Pasaman Padang (Sulaiman et al., 2009) dan penguatan kapasitas khatib di perbatasan (Ibrahim \& Yusriadi, 2020). Selanjutnya, kajian pendampingan terkait penguatan dai millennial di ruang maya di Kota Medan Sumataera Utara (Nashrillah, 2019) dan pengembangan performance dakwah hasanah (Tajiri, 2010). Beberapa kajian terdahulu cukup memberikan gambaran bahwa pelaksanaan pelatihan yang disertai pendampingan bagi para dai belum banyak dilakukan dan menjadi urgen. Selain itu, belum adanya pendampingan dai muda di wilayah Papua Barat menjadi opsi untuk segera melakukan pelatihan dan pendampingan. Dengan kata lain pengabdian ini menjadi pilihan menarik dalam peningkatan kompetensi dai para kaum muda yang ada.

Pengabdian ini dasarkan pada argument bahwa, pelatihan dan pendampingan efektif dalam meningkatkan kualitas dai muda di wilayah Papua Barat. Seperti yang dikatakan Suharto bahwa pendampingan merupakan penentu keberhasilan program pengabdian masyarakat yang mengutamakan making the best of the client's resources (Payne, 2006; Suharto, 2005). Selain itu difungsikan sebagai kegiatan bersama dalam mencermati persoalan nyata dan mendiskusikan nya untuk mendapatkan pemecahan ke arah peningkatan kapasitas dan produktivitas (Hartono et al., 2018; Payne, 2006). Kemudian, penguatan atas permasalahan yang ada ditingkatkan dengan pelatihan yang efektif. Ini berarti berkaitan dengan pengetahuan, keahlian dan perilaku para peserta dampingan (Dessler, 2013; De Cieri et al., 2003; Yudiawan et al., 2020). Efektivitas pelaksanaan kegiatan ini mencakup pembelajaraan atas pengalamanpengalaman, yang direncanakan dan dirancang untuk menanggapi kebutuhan-kebutuhan yang teridentifikasi. Ini menjadi bukti bahwa, pendampingan dan pelatihan relevan menjadi pilihan untuk peningkatan kualitas dai muda dalam kaitannya dengan respon masyarakat yang ada.

Secara umum, pengabdian ini bertujuan untuk optimalisasi kualitas dai muda, khususnya para mahasiswa di IAIN Sorong Papua Barat. Selain sebagai tanggung jawab keilmuan mahasiswa, juga merupakan bentuk tanggungjawab kelembagaan pada masyarakat. Jika dilihat dari substansi pengabdian, difokuskan pada upaya peningkatan keilmuan dan ketrampilan dalam berdakwah yang akan dilihat pada enam aspek kompetensi dai. Keenam aspek tersebut diantaranya terkait kemampuan dalam memahami adab, kemampuan penyampaian (nada), penguasaan materi, panggung atau majelis, makharijul huruf dan tajwid dan efektivitas waktu dalam pemberian tausyiah atau dakwah (Syafaruddin et al., 2020; Syafa, 2015). Dengan memahami aspek ( 6 aspek) ini, maka diharapkan kualitas dai muda dapat semakin optimal dan 
siap berkontribusi dalam masyarakat. Akhirnya benteng keislaman di wilayah minoritas muslim Papua Barat dapat terus terjaga dan mampu ditingkatkan.

\section{Metode}

Pengabdian ini dilaksanakan selama 1 bulan (29 Februari sampai 29 Maret 2020) dengan 10 kali kegiatan pertemuan. Bentuk pengabdian adalah pendampingan dan pelatihan. Subjek pengabdian adalah mahasiswa aktif penerima bantuan bidik misi di IAIN Sorong. Peserta dampingan berjumlah 20 orang, dengan rincian 12 orang perempuan dan 8 orang laki-laki. Digunakan pendekatan Participatory Action Research (PAR) dalam pelaksanaan kegiatan. Pendekatan ini memiliki keutamaan karena melakukan riset sekaligus aksi partisipatif, dimana dilakukan pengarahan, perbaikan, dan pengevaluasian keputusan atas langkah-langkah yang dilakukan bersama. Mitra kolaborasi dibangun bersama peneliti, tokoh agama (ustadz) dan mahasiswa penerima bantuan bidik misi. Selanjutnya dirumuskan langkah pemecahan masalah yang ada bersama mitra dan perubahan apa yang diharapkan. Pada tahap akhir, akan dianalisis temuan yang ada sebagai tawaran teoritis konseptual dan dipublikasikan pada kanal publik, (Holter \& Schwartz-Barcott, 1993; Zuber-Skerritt, 2015). Pendekatan Participatory Action Research (PAR) berbentuk siklus dengan empat tahapan Tindakan setelah pesrmasalahan terindentifikasi, yaitu: rencana, tindakan, observasi, dan refleksi (lihat gambar 1) (Kemmis and McTaggart, 2000).

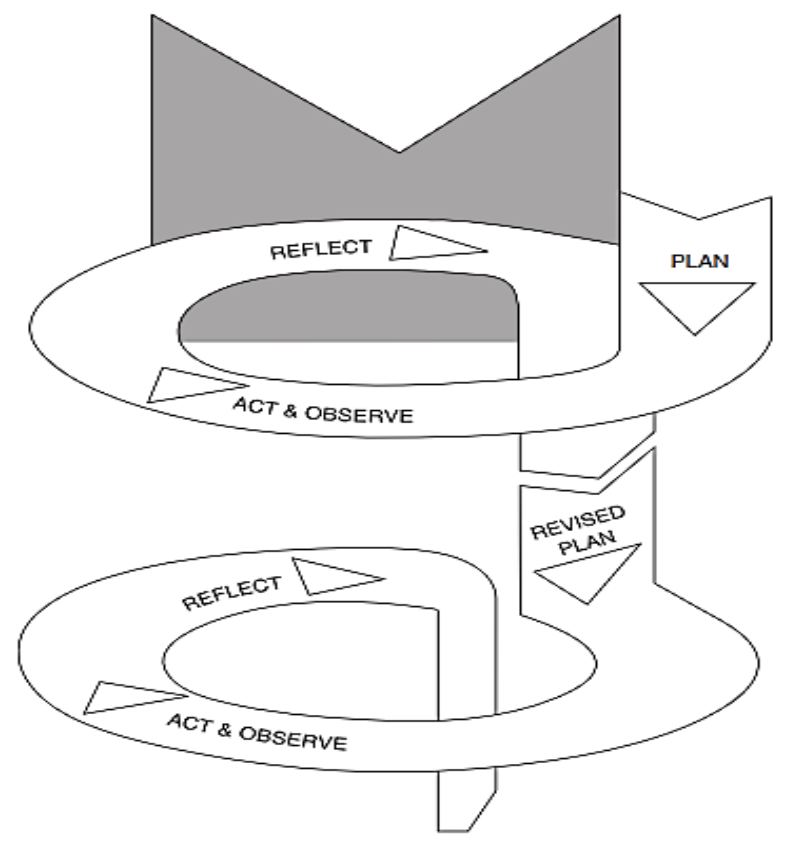

Gambar 1. Langkah Participatory Action Research

Selanjutnya, pada awal kegiatan dan akhir pendampingan diberikan penilaian. Penilaian didasarkan pada 6 (enam) indikator yaitu: 1) sikap serta penampilan (aspek adab); 2) Nada (aspek intonasi dan artikulasi); 3) kesesuaian materi dan isi; 4) Penguasaan panggung; 5) Makharijul huruf, tajwid dan arti dalil dan 6) pemanfaatan waktu. Hasil penilaian tiap indicator 
selanjutnya dibuatkan kriteria untuk mengukur keberhasilan peserta dampingan. Adapun kriteria kualitas dampingan digunakan pengukuran menurut (Arifin, 2009) yaitu;

Tabel 1. Kriteria Tingkat Keberhasilan Belajar

\begin{tabular}{cc}
\hline Tingkat Keberhasilan (\%) & Kriteria \\
\hline$>80$ & Sangat Baik \\
\hline $71-80$ & Baik \\
\hline $61-70$ & Cukup Baik \\
\hline $51-60$ & Kurang Baik \\
\hline$<50$ & Buruk \\
\hline
\end{tabular}

Sumber: Dikutip dari Arifin (2009)

\section{Hasil dan Pembahasan}

\section{Hasil Pendampingan}

Sebelum melaksanakan pendampingan model pelatihan dai muda, diberikan kesempatan kepada seluruh peserta untuk memberikan ceramah singkat sebagaimana ditunjukkan pada gambar 2. Materi yang disampaikan berkaitan dengan isu keislaman sesuai dengan instruksi pendamping sebelum pelaksanaan dilakukan. Tiap peserta diberikan penilaian sesuai dengan enam indikator penilaian dai. Selanjutnya, hasil penilaian dilakukan tabulasi untuk melihat kompetensi awal peserta pendampingan. Adapun hasil tabulasi data peserta sebelum dilakukan pendampingan dan pelatihan ditampilkan pada tabel 1 berikut ini.

Tabel 1. Rata-Rata Capaian Kompetensi Dai Muda Sebelum Pendampingan

\begin{tabular}{clcc}
\hline No. & \multicolumn{1}{c}{ Indikator } & Capaian & Kriteria \\
\hline 1 & Sikap serta penampilan (aspek adab) & 65,8 & Cukup Baik \\
2 & Nada (aspek intonasi dan artikulasi) & 52,6 & Kurang Baik \\
3 & Kesesuaian materi dan isi & 61,2 & Cukup Baik \\
4 & Penguasaan panggung & 55,6 & Kurang Baik \\
5 & Makharijul huruf, tajwid dan arti dalil & 63,2 & Cukup Baik \\
6 & Pemanfaatan waktu & 50,0 & Kurang Baik \\
& Rata-Rata Capaian & 58,1 & Kurang Baik \\
\hline
\end{tabular}

Sumber: Data Pra Pendampingan (2020)

Beberapa kondisi yang terlihat pada tabel 1 cukup memberikan gambaran bahwa ratarata komptensi para dai muda tergolong kurang baik $(58,1)$. Aspek pelafalan dan intonasi, penguasaan panggung (mimbar) dan waktu berada pada kriteria terendah dibandingkan lainnya. Sementara pada ketiga aspek lainnya, aspek adab, kesesuaian materi dan makhorijul huruf tergolong cukup baik dan perlu dilakukan optimalisasi.

Selanjutnya dilakukan pendampingan intensif kepada para peserta dampingan, (Gambar 3 dan 4). Pendampingan dilakukan oleh tiga orang ahli diantaranya: 1) Kyai Ahmadi, M.Pd. (Rais Syuriah PW NU Papua Barat; 2) H. Muyono, S.Ag., M.Pd. (Pengurus NU Kota Sorong), dan 3) Ust. Muhyidin, S.Ag., M.Th. I (Dai muda Papua Barat). Proses pendampingan dilakukan pada hari Sabtu dan Minggu selama 8 kali (2 kali pertemuan lainnya adalah untuk tes pra dan pasca pendampingan). Pelaksanaan dilakukan di Masjid Kampus (untuk pelatihan dan unjuk kerja) 
dan gedung tarbiyah (untuk pendalaman subtansi isi). Kondisi pelaksanaan pendampingan dan pelatihan dapat dilihat pada gambar 2-5 berikut.

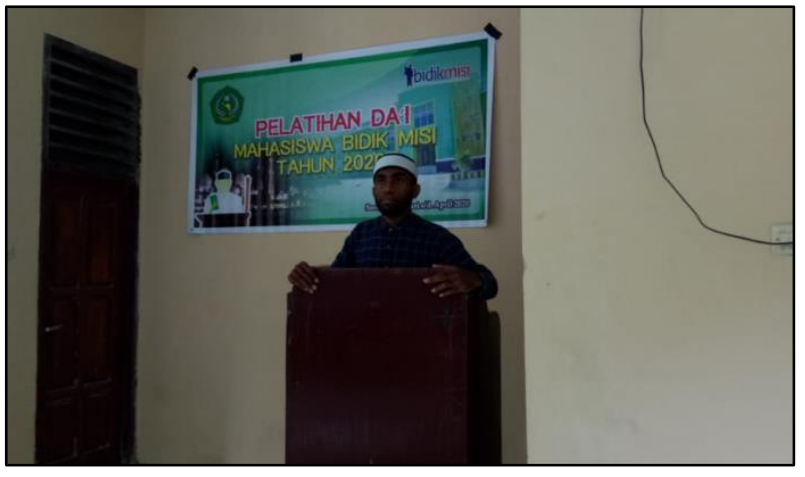

Gambar 2. Unjuk kerja pra pendampingan

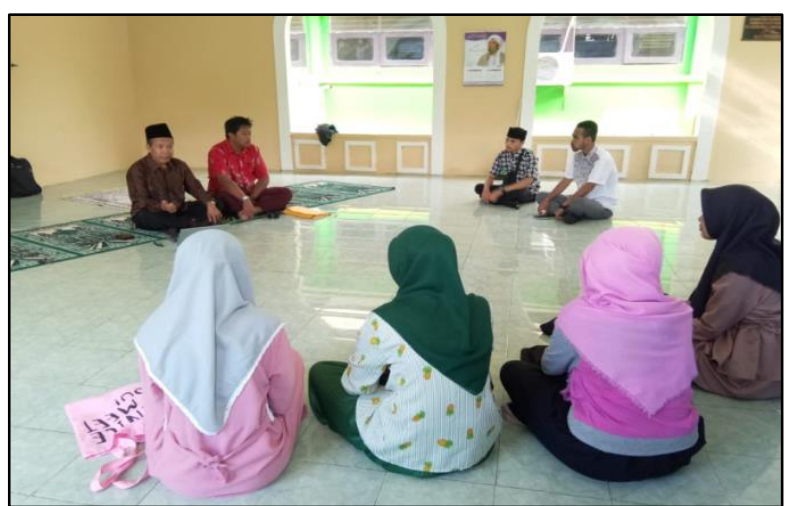

Gambar 4. Proses Pendampingan

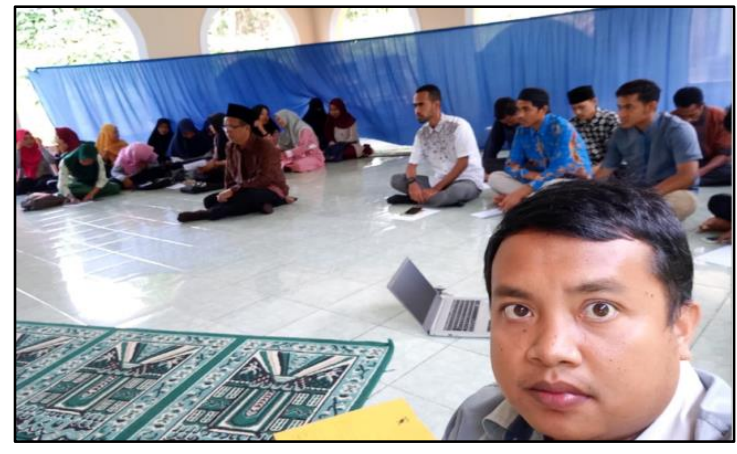

Gambar 3. Proses Pendampingan

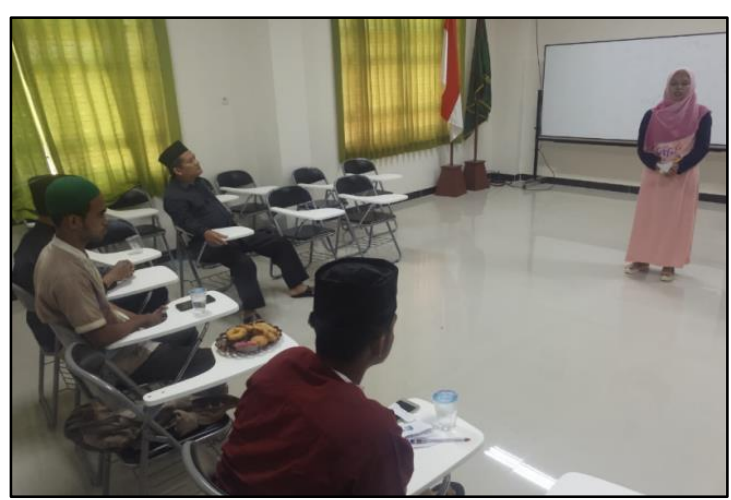

Gambar 5. Evaluasi Pasca Pendampingan

Selanjutnya, setelah dilakukan pendampingan intensif selama 8 kali, seluruh peserta pelatihan diberikan tes evaluasi, (Gambar 5). Evaluasi dilakukan untuk mengukur capaian kegiatan pendampingan dan pelatihan. Setiap peserta diminta untuk memberikan tausiah atau dakwah langsung didepan peserta lainnya dan pendamping. Pendamping memberikan respon dan penilaian untuk selanjutnya dianalisis sebagai ukuran capaian kegiatan. Adapun hasil ratarata kemampuan peserta pasca pendampingan dapat dilihat pada tabel 2 .

Tabel 2. Rata-Rata Capaian Kompetensi Dai Muda Pasca Pendampingan

\begin{tabular}{clcc}
\hline No. & \multicolumn{1}{c}{ Indikator } & Capaian & Kriteria \\
\hline 1 & Sikap serta penampilan (aspek adab) & 82,2 & Sangat Baik \\
2 & Nada (aspek intonasi dan artikulasi) & 68,4 & Cukup Baik \\
3 & Kesesuaian materi dan isi & 78,0 & Baik \\
4 & Penguasaan panggung & 72,2 & Baik \\
5 & Makharijul huruf, tajwid dan arti dalil & 76,6 & Baik \\
6 & Pemanfaatan waktu & 78,8 & Baik \\
& Rata-Rata Capaian & 76,0 & Baik \\
\hline
\end{tabular}

Sumber: Data Pasca Pendampingan (2020)

Pada tabel 2 diatas dapat dilihat bahwa rata-rata capaian kompetensi peserta dampingan berada pada kategori baik $(76,0)$. Sikap (adab) peserta dampingan berada pada kriteria paling tinggi (sangat baik, 82,2), sementara paling rendah adalah kriteria penguasaan nada (intonasi dan artikulasi) pada kategori cukup $(68,4)$. Dapat dikatakan bahwa, pasca pendampingan 
kemampuan peserta semakin baik dibandingkan sebelumnya. Adapun peningkatan kompetensi dai muda sebelum dan setelah pendampingan dapat dilihat pada gambar 6 .

Gambar 5 menampilkan peningkatan kompetensi dai muda sebelum dan setelah pendampingan dilaksanakan. Peningkatan terjadi pada seluruh aspek indicator yang ditetapkan. Peningkatan tertinggi terjadi pada asepk pemanfaatan waktu (29\%), diikuti aspek keseseuaian materi dakwah dan penguasaan panggung (17\%). Selanjutnya, aspek sikap dan kemempuan intonasi dan artikulasi mengalami peningkatan $16 \%$. Secara umum, kompetensi dai muda dapat ditingkatkan melalui pendampingan dan pelatihan yang dilakukan. Olehnya, pelatihan dan pendampingan dapat menjadi pilihan dalam penyiapan para calon dai muda untuk berdakwah khsusnya di wilayah Papua Barat.

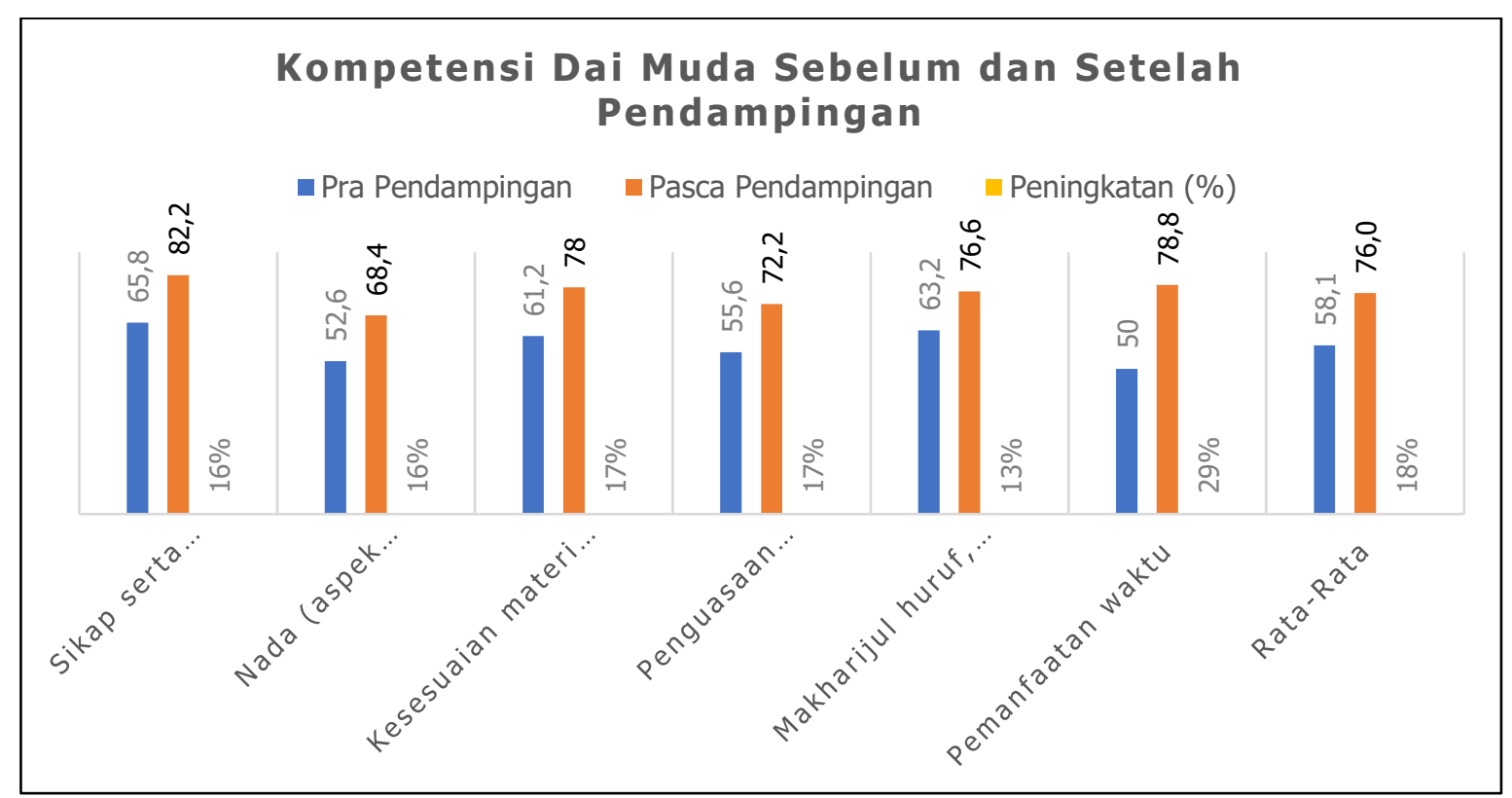

Gambar 6. Peningkatan Kompetensi Dai

\section{Pembahasan}

Hasil penelitian menunjukkan peningkatan kompetensi dai muda dalam memahami konteks dakwah di wilayah minoritas muslim. Sebelum adanya pendampingan dan pelatihan, kompetensi para dai muda berada pada kategori kurang baik yaitu 58,1. Hal ini dapat terjadi dikarenakan mahasiswa sebagai peserta dampingan belum memahami secara subtantif dan teknis bagaimana model dakwah yang baik. Kampus hanya menyediakan bahan diskusi keilmuan dan minim implementasi praktis dalam dakwah. Mereka yang siap hanya beberapa, dikarenakan lulusan dari pondok pesantren dengan basis keislaman masyarakatnya kuat. Pelimpahan tanggungjawab sebagai tokoh muda dipercayakan kepadanya. Ini adalah nilai tambah. Namun, lainnya (peserta) belum memiliki pemahaman dan kesempatan ini. Setelah dilakukan pendampingan, kompetensi secara klasikal dapat ditingkatkan menjadi 76,0 atau pada kategori baik. Peningkatan sebesar $18 \%$ dikarenakan pendampingan dan pelatihan yang kontinu dengan melibatkan para tokoh agama dan dai milenial sebagai bahan refernsi konkrit. 
Pelatihan dan pendampingan ini secara teori dibenarkan oleh Windrawanto et al., (2019), bahwa pendampinagan dan pelatihan dapat meningkatkan kecakapan hidup (life skills) para pemuda. Kehebatan para pemuda dalam melakukan pembenahan dan perubahan masyarakat dikarenakan peran yang dimilikinya (Prayitno, 2017). Pemuda yang merupakan agen of change, akan mudah untuk diberikan penguatan, apabila diajak untuk bersama mendiskusikan permasalahn yang dihadapinya dan masyarakat. Model pendampingan dan pelatihan ini, menjawab kebutuhan yang ada. Adanya pembelajaran yang memungkinkan untuk melakukan identifikasi kebutuhan belajar yang diperlukan, tentu akan mempermudah dalam melakukan pengembangan diri para pemuda. Selain itu shering pengalaman dan pengetahuan antar pendamping dan peserta mempertajam penguasaan pengetahuan yang ada (Depdiknas, 2003; Payne, 2006). Pada akhirnya pegetahuan dan keahlian peserta dampingan dapat ditingkatkan dengan efektif dan efesien (Dessler, 2013; De Cieri et al., 2003). Selain itu, pendampingan merupakan penentu keberhasilan program pengabdian masyarakat yang mengutamakan making the best of the client's resources (Payne, 2006; Suharto, 2005). Dapat dikatakan bahwa, upaya pendampinagan dan pelatihan secara teoritis mampu dibenarkan dalam peningkatan kompetensi peserta dampingan.

Selanjutnya, hasil temuan ini sejalan dengan temuan Ayyub (2012), dimana dai muda dapat dengan mudah dilakukan optimalisasi dengan melakukan pendampingan. Pendampingan ini membuktikan bahwa para pemuda islam dapat diajak berkolaborasi dalam menentukan kualitas dirinya, kaitanya dengan dakwah di wilayah minoritas muslim Papua Barat. Berbeda dengan daerah lainnya yang memiliki basis muslim mayoritas. Model pengabdian masyarakat seperti kajian rutin, webinar keislaman dan bentuk-bentuk pendampingan kekinian dapat dilakukan (Risdiana, 2014; Sulaiman et al., 2009). Namun, di Papua Barat sangat berbeda, tipologi masyarakat dan budaya yang ada sangat berbeda (Wekke, 2017). Olehnya temuan atas model pegabdian masyarakat yang terfokus pada pendampingan dan pelatihan dapat menjadi pilihan menarik dalam pengembangan para pemuda dan masyarakat muslim minoritas.

Kaum muda Papua lebih membutuhkan pendampingan dalam memastikan track kompetensi yang dimiliki. Ilmu yang dimiliki tanpa adanya pendampingan yang baik dan berkesinambungan, maka akan menjadi hilang tak terasah (Nani, 2019). Cukup banyak pelatihan dan peningkatan kompetensi yang dilakukan, baik sektor agama, pendidikan dan soft skill lainnya, namun saat itu diberikan kompetensi nya bertambah, dan esoknya akan hilang. Dengan kata lain, pelatihan yang dilanjutkan dengan pendampingan yang masif akan berkontribusi pada eksistensi kompetensi yang dimiliki. Disini peran pendamping menjadi sentral dalam mengaktualisasikan kompetensi yang dimiliki pemuda. Pendamping dituntut lebih terbuka dan paham atas budaya masyarakat yang ada. Tujuannya agar proses dampingan pasca pelatihan dapat terus diupayakan dengan dukungan penuh pemuda dan masyarakat yang ada.

Beberapa pembahasan diatas cukup memberikan dasar bahawa, para mahasiswa (calon dai muda) harus dibekali dengan kompetensi keagamaan yang praktis dimasyarakat. Dengan demikian maka, agen of change, social contro/dan iron stock dapat diwujudkan dengan segera. Dampaknya, masyarakat wilayah minoritas muslim Papua Barat tidak akan lagi kekurangan stok dai yang mumpuni. Selain itu, mereka akan segera siap mengabdi dimasyarakat baik dari sisi 
keilmuan dan keagamaan. Dari hal ini, maka dapat dikatakan bahwa benteng pertahanan islam tetap terus dapat dipertahankan.

\section{Kesimpulan}

Upaya peningkatan kualitas dan kuantitas dai di wilayah minoritas muslim Papua Barat harus terus dilakukan. Utamanya mahasiswa pada perguruan tinggi keagamaan islam sebagai tokoh muda, akan terus diberikan tanggungjawab keagamaan masyarakat. Selain minim stok, juga minim keilmuan, sehingga pada akhirnya selalu mendatangkan dai diluar wilayah Papua Barat. Hal ini tentu akan sedikit menyulitkan, disamping wilayah yang sulit akses (gunung dan hutan), juga belum memahami kultur kedaerahan yang berbeda-beda. Pilihanya adalah, penyiapan para dai sesuai kultur kewilayahan, dengan berbagai metode. Pelatihan dan pendampingan terbukti efektif dalam menjawab persoalan yang ada. Pelatihan sebagai sarana penguatan kompetensi praktis, sementara pendampingan diposisikan dalam aspek subtansi keilmuan. Mahasiwa di Papua Barat memiliki kultur yang berbeda dengan wilayah lain, jika hanya diberikan pelatihan maka pemahaman hanya sesaat, olehnya pendampingan berkelanjutan merupakan suatu keniscayaan. Agar kompetensi yang diberikan tidak mudah hilang dan dapat bertahan. Selain itu, kami merekomendasikan agar peran masyarakat, tokoh agama, dan pemerintah (kementerian agama wilayah, MUI, Dewan Dakwah Wilayah), harus beriringan dalam melihat persoalan ini. Kampus hanya menyiapkan, selanjutnya para stakeholder yang memberikan pembniaan dan pengarahan agar ilmu yang dimiliki lulusan (mahasiswa) tidak mati suri. Selain itu, misalnya kementerian Agama, harus memberikan ruang dan kesempatan yang luas, agar bekal ilmu agama yang dimiliki saat dikampus dapat diimplementasikan secara berkesinambungan.

\section{Ucapan Terima Kasih}

Pendamping menyampaikan ucapan terimaksih kepada pihak terkait dalam mendukung suksesnya pelaksanaan pelatihan dan pendampingan ini. Utamanya kepada Wakil Rektor III Bidang Kemahasiswaan dan sekaligus sebagai penaggungjawab mahasiwa Bidikmisi yang mempercayakan pengelolaan dana penguatan kemahasiswaan dibidang dakwah. Selain itu, Rektor IAIN Sorong yang terus mendukung upaya penguatan kapasitas keagamaan mahasiswa melalui berbagai program kegiatan. Kemudian, para tokoh agama, dai dan rekan kerja yang berkontribusi langsung dan tidak langsung dalam mendukung suksesnya kegiatan dimaksud. Semoga, upaya kita dapat menjadi berkah demi kemajuan masyarakat islam khsusnya, dan sumber daya manusia di Papua Barat secara umum.

\section{Referensi}

Ahmadi. (2020). Wawancara, Perkembangan Islam di Papua Barat.

Arifin, Z. (2009). Evaluasi pembelajaran. Bandung: PT Remaja Rosdakarya.

Ayyub, A. (2012). Dai dan Pengembangan Masyarakat Islam (Peranan Dai dalam Mensosialisasikan Motto Kendari Kota ,Bertakwa' di Kota Kendari). Universitas Islam Negeri Alauddin Makassar.

De Cieri, H. L., Kramer, R., Noe, R. A., Hollenbeck, J. R., Gerhart, B., \& Wright, P. M. (2003). Human 
resource management in Australia. Strategy-people-performance. McGraw-Hill Education.

Depdiknas. (2003). Undang-Undang Republik IndonesiaTahun 2003 tentang sistem pendidikan nasional. Jakarta: Depdiknas.

Dessler, G. (2013). Strategic human resource management and the HR scorecard. Prentice Hall.

Hartono, H., Lesmana, C., Permana, R., \& Matsun, M. (2018). Pelatihan dan pendampingan pembuatan media pembelajaran berbasis multimedia interaktif. Transformasi: Jurnal Pengabdian Masyarakat, 14(2), 139-147.

Holter, I. M., \& Schwartz-Barcott, D. (1993). Action research: what is it? How has it been used and how can it be used in nursing? Journal of Advanced Nursing, 18(2), 298-304. https://doi.org/10.1046/j.1365-2648.1993.18020298.x

Ibrahim, I., \& Yusriadi, Y. (2020). Penguatan Kapasitas Dai Dan Khatib Untuk Moderasi Islam di Perbatasan. ICRHD: Journal of Internantional Conference on Religion, Humanity and Development, 1(1), 83-96.

Kemmis and McTaggart. (2000). Participatory Action Research, Handbook of qualitative research. Sage.

Mashad, D. (2015). Muslim Papua: Membangung Harmoni Berdasar Sejarah Agama di Bumi Cendrawasih. Pustaka Al-Kautsar.

Nani, N. (2019). Teknik Pelatihan Calon Dai Dalam Membentuk Da'i Profesional Pada Unit Kegiatan Mahasiswa (UKM) Rumah Da'i Fakultas Dakwah Dan IImu Komunikasi UIN Raden Intan Lampung. UIN Raden Intan Lampung.

Nashrillah, M. (2019). Aktualisasi Dakwah Dai Millennial di Ruang Maya: Perspektif Etika Dakwah dengan Studi Kasus di Kota Medan. Jurnal IImiah Islam Futura, 18(1), 105. https://doi.org/10.22373/jiif.v18i1.3196

Payne, M. (2006). What is professional social work? Policy Press.

Pdppkemenag. (2019). Statistik Data Pondok Pesantren di Papua Barat. Kemenag. https://ditpdpontren.kemenag.go.id/pdpp/statistik?id=92

Prayitno, P. (2017). Konseling Profesional yang Berhasil: Layanan dan Kegiatan Pendukung. Rajawali Press.

Ramadhan, R. (2015). Peran dan Fungsi Mahasiswa. Kompasiana. https://www.kompasiana.com/ rezaramadhanunj/55dadb8a54977303099134c5/peran-dan-fungsi-mahasiswa

Risdiana, A. (2014). Transformasi Peran Da'i Dalam Menjawab Peluang Dan Tantangan (Studi Terhadap Manajemen SDM). Jurnal Dakwah, 15(2), 433-451. https://doi.org/https://doi.org/10.14421/jd.2014.15210

Suharto, E. (2005). Membangun Masyarakat, Memberdayakan Masyarakat. In Refika Aditama. Refika Aditama.

Sulaiman, S., Wirdati, W., Ismet, S., \& Wirman, A. (2009). Pelatihan Khatib dan Mubaliqh Muda SeKanagarian Tanjung Betung Rao Selatan Pasaman. Universitas Negeri Padang. http://repository.unp.ac.id/id/eprint/17751

Syafa, A. R. (2015). Kompetensi Dai Muda Papua. Pesona Grafindo.

Syafaruddin, S., Siahaan, D. N. A., Assingkily, M. S., \& Siregar, T. (2020). Pelatihan Da'I Muda Sumatera Utara. Jurnal Abdi Mas Adzkia, 1(1), 1-8.

Tajiri, H. (2010). Ikhtiar Mengembangkan Performance Dakwah Hasanah dari Perspektif Etika Dakwah. Anida, g(1). https://doi.org/10.15575/anida.v9i1.584

Wekke, I. S. (2017). Harmoni Sosial Dalam Keberagaman Dan Keberagamaan Masyarakat Minoritas Muslim Papua Barat. KALAM, 10(2), 295. https://doi.org/10.24042/klm.v10i2.3

Windrawanto, Y., Irawan, S., \& Setyorini, S. (2019). Pelatihan Dan Pendampingan Kelompok Pemuda Dalam Peningkatan Pelayanan Dan Pengelolaan Kawasan Obyek Wisata Candi Cetho. CARADDE: Jurnal Pengabdian Kepada Masyarakat, 1(2), 167-173. https://doi.org/10.31960/caradde.v1i2.38

Yudiawan, A. (2020). Rekonstruksi Manajemen Mutu Pesantren. AL-FIKR: Jurnal Pendidikan Islam, 5(2), 10-17. https://doi.org/10.32489/alfikr.v5i2.22

Yudiawan, A., Rusdin, R., Chudzaifah, I., \& Sari, F. (2020). Pendampingan dan Optimalisasi Kompetensi Guru dalam Penulisan Artikel IImiah melalui Web Seminar pada masa pandemi COVID-19 di Papua Barat. Community Empowerment, 5(2), 64-72. https://doi.org/https://orcid.org/0000-0002-4386-7072 
Transformasi: Jurnal Pengabdian Masyarakat, Vol. 16, No. 2, Desember 2020: 155-164

Zuber-Skerritt, O. (2015). Participatory action learning and action research (PALAR) for community engagement: A theoretical framework. Educational Research for Social Change, 4(1), 5-25. 